\title{
From HeTEROGLOSSIA TO POLYGLOSSIA: THE CREATION OF MALAY AND DUTCH IN THE INDIES
}

\author{
H.M.J. Maier
}

Some data about the final years of the Dutch Indies for a start: in 1930, 3,746,225 natives could read and write; this was 6.44 percent of the total native population of the Indies. In the same year, 75.2 percent of the Europeans (180,504 people) were considered literate, and 28.9 percent (or 344,147 people) of the Chinese population. Of the Europeans, 172,089 people could write Dutch, of the natives 187,708 (0.3 percent), and of the Chinese 40,095.

Of the then almost 61 million inhabitants of the Dutch Indies, 1,482,402 children were registered as pupils of primary and continuation vernacular education. Of the children between 6 and 9 years of age, 34.5 percent were registered as "going to a school." Read against the background of the 6 percent literacy of the population as a whole, the report claimed that literacy was on the rise; but then almost half of these children were to leave school before they had finished the three years' curriculum available to them.

These figures, of course, only make sense when read against the background of other figures. They demand a kind of intertextuality, so to speak, like any other sentence, phrase, or statement. Intertextuality may be infinite, and this may apply to figures as well, yet some sorts of intertextuality are more relevant than others. This is where manipulation, selection, and misreading come into play under the name of interpretation.

\section{The 1930 Census: Literacy and Language}

The total population of the Dutch Indies for 1930 was estimated at $60,727,000$ people. Of these, say, 61 million, 240,000 were registered as Europeans, 59,138,000 as natives (or Indonesians), 1,233,000 as Chinese; 0.40 percent, 97.38 percent, and 2.03 percent of the total

\footnotetext{
${ }^{1}$ An earlier version of this essay was presented at the conference "Authoritative Words-Strategies of Communication in South and Southeast Asia," held at the University of Wisconsin-Madison, May 9-11, 1991, and sponsored by the Center for South Asian Studies, the Center for Southeast Asian Studies and the Social Science Research Council. I wish to give a special word of thanks to Toby A. Volkman and Alton Becker.
} 
population, respectively. Forty-two million were living in Java and Madura. Sixty percent of the Europeans lived in the twelve big cities of the Indies, 54 percent in the six big cities of Java. Of the Europeans in 1930, 70 percent were born and raised in the Indies. Interesting data indeed.

Most of these figures were taken from the 1930 Census, published by the Department of Economic Affairs in Batavia between 1933 and 1936 in eight volumes. ${ }^{2}$ Some are quotations from the so-called "Visman-rapport," the product of a commission installed by the Governor-General of the Dutch Indies in September 1940, shortly after the German occupation of the Motherland. Visman and his colleagues had been given the task of looking into the question of how the Constitution of the Indies should be reformed so as to bring it into tune with the times. With this aim, the commission had registered the political wishes and desires of the various groups in the Indies, working under the illusion that it was not yet too late to embark on constructing an "Indische" state, a distinct cultural identity, an integrated nation, a harmonious society. The last convulsion of a dream, as the sociologist J. van Doorn was to call it later. ${ }^{3}$ In the last fifty years of colonial rule, Dutch Indies' society had become too segregated along racial lines; too many people had already entrenched themselves in bitterness, arrogance, and ignorance to make such a dream ever come true.

Now, is the 6.44 percent literacy rate among natives as registered by the 1930 Census really that negative in comparison with the 75.2 percent among the Europeans? In absolute numbers, twenty times more natives could read and write than Europeans, claims the Census Report's chapter on education, and did not the Dutch Indies Government deserve due respect for this achievement? This tone was set by the most respected authority in the field of education at the time, Professor I. J. Brugmans, who wrote the chapter on education in the Visman-rapport and was to make a substantial contribution to Balans van Beleid, that eerie and authoritative defense of colonial rule published in 1960. In Brugmans' view, the educational policy in the Indies "amply met the requirements that could reasonably be made. There is no reason for the Dutch to put on the hair shirt, a dress that is too much loved in some circles. The Dutchman should not congratulate himself either. He just did his duty." 4

This was a matter of perspective, no doubt. And of interpretation. The same could be said, for instance, of the 1948 report of the Department of Education in Batavia, which stated that, had the percentage of illiteracy been calculated according to the criteria used by the then US Government, only 69.17 percent of the total Dutch Indies population would have been registered as illiterate instead of the 93 percent. Figures and numbers are dangerous and poly-interpretable, so it seems, like every form of language.

In the Census Report of 1930 a separate chapter was dedicated to literacy and illiteracy, an indication of the importance the Indies Government attached to the educational apparatus that had been set up to elevate the natives and train the Europeans. Among many things, the report shows us that illiteracy can be approached from a number of perspectives. 75.2 percent of the Europeans may be registered as literate, 6.4 percent of the natives; but then, a different perspective leads to different numbers: in 1930, the Census tells us, 4

2 Volkstelling 1930. 8 vols. (Batavia: Departement van Economische Zaken, 1933-1936).

3 J. van Doorn, A Divided Society (Rotterdam: Casp, 1983), p. 10.

4 "heeft ruimschoots aan redelijke eisen beantwoord. $\mathrm{Er}$ is voor de Nederlanders geen enekele reden het boetekleed, een in sommige kringen geliefd kledingstuk, aan te trekken. Evenmin behoeft de Nederlander zich op de borst te kloppen; hij heeft eenvoudig zijn plicht vervuld" I. J. Brugmans in "Onderwijspolitiek," in Balans van Beleid-Terugblik op de laatste halve eeuw van Nederlandsch-Indië, ed. J. Baudet and I. J. Brugmans (Assen: van Gorcum, 1960), pp. 168-69. 
percent of the Europeans over 19 years of age were illiterate, 93 percent of the natives over 15 years of age.

Such statements should, of course, have been preceded by a more careful exploration of terms like literacy and illiteracy. Figures would have been different, if Arabic and Javanese script had been taken into account as well as Western presentations of language and if, for example, schooling in so-called religious institutions had been included in the Census. The number of people who knew the Koran and were able to read it and were able to read a Malay or Javanese text in Arabic script can not be found in the report; neither can the number of those who read Javanese script or Batak or Bugis script for that matter. And why, by the way, does the census make this strange distinction in age between 18 years for Europeans and 15 years for native youths?

Censuses have to be read carefully and cautiously, no matter how reliable their figures claim to be, and the 1930 Census Report is no exception to that rule, neither in its claims nor in the caution it requires. The lists, graphs, and figures in the 8-volume report are impressive and interesting, but at least as interesting are the questions that led to these figures, lists, and graphs. Reading could even go beyond this point: the selection of some questions and categories and the neglect of others should tell us a great deal about the nature of societal relations as presented by Authority, and the same could be said of the criteria which the census administrators used to differentiate among groups, classes, and races. In short, a fine reflection of an authoritative ideology which tried to express and explore political power and economic possibilities in many ways.

The classification into three groups-"Europeans," "Natives," and "Chinese \& other foreign Orientals" -is presumably based on the division introduced by the Law of December 31, 1906 (which, curiously enough, was not made operative until January 1, 1920). It reads like a mainly racial classification, and, as such, the report presents a reflection of the plural and judicial organization of Dutch Indies society.

Equally indicative for Authority is the detailed specification of the relatively small group of European inhabitants of the Indies; set against the relatively less detailed figures about so many more natives, it is almost embarrassing to be given so much detailed information about the superior race. The careful subcategorization of the native population in ethnic units on the basis of their geographical location may be illustrative as well: this emphasis on ethnic differences could easily be read as yet another indication of Authority's effort to preserve the segregation of the Indies' population. The natives had to be made aware of the differences among themselves, in terms of race, tribes, cultures, languagesan awareness that could not but make Dutch-dominated rule somewhat easier.

Obviously, the tripartite classification hid a wide variety of tensions and divisions in everyday life in the Dutch Indies. There are numerous narratives about those who tried to become accepted as Europeans and those who were refused the privileges of Europeans, and, conversely, about those who refused to accept the natives as their equals and those who refused to accept the Europeans as their equals. Let it suffice to quote a paragraph from the diary that Sutan Sjahrir, one of the native leaders, kept during his exile in the 1930s:

With a great amount of understanding and tolerance, one could try to accept this colonial life with its nonsensical relationships and its psychopathic inhabitants - on the one hand the sadists and those who suffer from megalomania, on the other hand the souls that are distorted by inferiority-complexes-in so far as one realizes that it is impossible to build a new world in a single day. (-) One can guard oneself from becoming the victim of colonial relationships, becoming one of those sick people with a distorted soul or 
become one of those sadists; one can make oneself immune against nonsensical, impotent hate. But even then it is impossible to forget that one is living among these sick people, these sufferers, these sadists. ${ }^{5}$

Sjahrir's Dutch is sharp and painful; faultless as well: it betrays a thorough training-and it makes one wonder if all those tens of thousands making up that 0.3 percent had mastered Dutch as well as Sjahrir had. It also makes one wonder about the excellent teachers he must have had-it is a pity so few natives were given the opportunity to learn Dutch.

Some ten years later, the report of the Visman Commission confirmed the tensions and conflicts here described. In a tone reminiscent of Sjahrir's in its coolness it is stated:

the general desire for complete equality with the Europeans, expressed by all nonEuropean representatives, made a very deep impression on the commission (-) Most of all, it was thought necessary to abolish all legal differences according to race which are felt as discriminatory, for how will society give up racial discrimination if the state does not give the example. (-) Objections were raised to the exclusive attitude which is adopted in many European circles against oriental groups as well as to the treatment that non-Europeans allegedly are given by the authorities. $(-)$ the univocal opinion of those who were interviewed is that social intercourse between persons of different races but of similar education is, generally speaking, limited. 6

Twenty years and a declaration of independence later, Van Marle ${ }^{7}$ showed that the term "European" had always been a deceptive one and that the idea of a superior "race" was justified neither by biological nor by cultural facts. In his string of essays, a fascinating survey of the arguments that were successively used by colonial Authority in Her efforts to determine who was to be a European (with all the privileges that came with that status) is followed by a detailed analysis of available data on marriages and concubinages. Van Marle's conclusion is revealing: the European population of the Dutch Indies was mainly of mixed blood (gemengdbloedig), and his suggestion is clear: the racial distinctions and subsequent discriminations which had obsessed almost everybody in Dutch Indies society were factually null and void. Divisions had been based on authoritative words-and in the first half of the twentieth century these words shaped racial segregation, barriers in social intercourse, and a strange distribution of labor and wealth.

\footnotetext{
5 "Men kan met veel begrip en verdraagzaamheid dit koloniale leven met de onzinnige verhoudingen en de psychopathische bewoners-aan de ene kant de sadisten en aan grootheidswaan lijdenden, aan de andere kant de door de minderwaardigheidscomplexen verwrongen zielen-trachten te aanvaarden, voor zover men inziet dat het toch niet mogelijk is er in één dag een nieuwe wereld van te maken. (-) Men kan zich ervoor hoeden zelf het slachtoffer te worden van de koloniale verhoudingen, zelf tot de zieken met de verwrongen zielen, de minderwaardighediscomplexen of tot de sadisten te gaan behoren, men kan zich immuun maken voor onzinnige, onmachtige haat. Maar men kan niet vergeten dat men tussen deze zieken, deze lijders en sadisten leeft." Sjahrazad, Indonesische overpeinzingen (Amsterdam: Bezige Bij, 1946), pp. 161-62.

6 "een van de diepste indrukken (Obij de commissie achtergebleven (is) de algemeene drang van alle nietEuropeesche representanten naar volleige gelijkheid met den Europeaan. (-)Allereerst werd nodig geacht de opheffing van alle wettelijke verschillen naar ras die als achterstelling worden aangevoeld, want hoe zal de maatschappij rasdiscriminatie loslaten indien de staat het voorbeeld niet geeft. (-) Bezwaren richtten zich zowel tegen de exclusieve houding, in vele Europese kringen aangenomen tegenover de oostersche groepen, als tegen de behandeling die niet-Euroeanen van overheidswege telkens zouden ondervinden (-) Het sociaal verkeer tusschen personen van verschillend ras maar gelijke ontwikkeling is over het algemeen, aldus het eenstemmig oordeel van alle gehoorden, gering." J. Visman, Verslag van de Commissie tot bestudeering van staatsrechtelijke hervormingen (Batavia: Landsdrukkerij, 1941), pp. 24 and 83.
}

7 See A. van Marle, "De groep der Europeanen in Nederland Indië, iets over ontstaan en groei," Indonesië (19511952) (The Hague: van Hoeve, 1952), pp. 96-121, 314-41, 481-505. 
Of course, the 1930 Census Report tells us much more: that the great majority of the leading positions in administration and industry were in the hands of Europeans, for instance, i.e. in the allegedly white hands of those who belonged to by far the smallest group; that relatively many of the European males were government officials, bureaucrats that is, the people who were told to clothe themselves in an aura of rationality and efficiency; that there were obvious differences in technological advancement between the white and the brown race and, concurrently, that one race was superior to the others, with an inherently greater potential. It was a fine illustration, in short, of the myth of the "white race" that the Dutch Indies Government had been ably preaching since the last part of the nineteenth century; and, concurrent with it, the myth of Dutch zakelijkheid:

The conscious fostering of a mystique of innate racial superiority, near-magical efficiency and the arcana of science. This myth was perhaps the most important single feature of Dutch colonial rule and allowed the Dutch to maintain total control of the vast archipelago with a colonial army of less than 40,000 men. ${ }^{8}$

The Census Report itself breathes the very professionalism, rationality, and efficiency one could not but expect from good administrators. The figures are accompanied by a carefully worded short preliminary analysis, presented in a self-confident and businesslike tone and, as a matter of course, the authors do not go into the question of why the population was divided along certain lines and not along others. Neither is the question raised of why literacy and education were thought to be important enough for treatment in a separate chapter. An arcana of science indeed!

For the Census designers, education must have become a self-evident feature of "good government" after 1901 when the so-called Ethical Policy was officially initiated and authoritative circles in The Hague and Batavia constructed some kind of consensus that the native population had to be elevated. Based on the uneasy combination of pragmatism and idealism, this consensus was of a delicate character; the question of how this elevation could be effectively implemented was never given a definite answer-and financial means were to remain limited to the very end. Should the native aristocracy be elevated first and given a Dutch training so that the aristocrats could provide their inferiors with the correct example? Should the proposed elevation be undertaken in a more radical manner and should all young children in the Indies be given a uniform education so that a distinct cultural identity could be constructed? Would it not make sense to give all of them some form of education? Who was to pay for the education of these millions? What was to be the role of Catholic and Protestant missionaries, and later of Muslim movements, for that matter? Painful questions, complicated answers.

Sooner or later such questions were to lead to the question of which language or languages should be used, which languages should be given priority among the wide variety of languages and dialects that were read and written, spoken and heard in the Indies.

The Census tells us that in 1930 only 5 percent of the native literates had a writing knowledge of Dutch. Or to put in yet another figure: only 0.3 percent of the native population as a whole had some sort of mastery of written Dutch: they were thought to be able to write a simple short letter (een eenvoudig briefje). A vague notion of active literacy, it seems, is used here for a standard (what is a short letter? what kind of letter?), and the report remains unclear on the question of how the ability to write such a letter had been tested, and why

\footnotetext{
8 See Benedict Anderson in "Japan: The Light of Asia," in Southeast Asia in World War II, ed. J. Silverstein (New Haven: Yale University Southeast Asian Studies, 1967), p. 17.
} 
the speaking alone of Dutch did not offer interesting figures in itself. Here and there, the Census administrators had added the reassuring phrase that their figures were very reliable indeed. One hundred and eight-seven thousand native inhabitants were recorded as having writing skills in Dutch, 400,000 inhabitants of the Indies were actively literate in Dutch. And so on and so forth.

The set of complementary questions, in retrospect so self-evident, is lacking, however: we are not told how many of the 70 million inhabitants in the Dutch Indies knew Javanese, Sundanese, Buginese. Obviously the Census worked from the assumption that languages are tied to regions and that there were only Javanese-speaking people in Central and East Java, that the inhabitants of the southern part of Sulawesi were Buginese and therefore knew only Buginese. Neither does the Census address the question of how many inhabitants of the Indies knew Malay in 1930, how many people could write and/or read Malay, let alone the self-evident question of how many Europeans knew Malay, or any other native language, for that matter. No doubt it would have been hard to define "to know Malay." Was this the skill "to write a simple short letter" in Malay? But what kind of Malay, and what kind of letter: an order to a taxi-driver or a question about the tenure of a piece of land to a local ruler? It would have been difficult to come up with reliable tests, had such questions be posed.

Who among the Europeans-apart from the rare language official, the missionary, the judge, the administrator, the military officer-would have had the courage to admit frankly that s/he had a good knowledge of Malay? Or did most Europeans think they did "know Malay" because they succeeded in making themselves "perfectly understandable" to their servants? And how about Javanese farmers in the hinterland of Surakarta: would they have any notion of Malay at all?

These are the sorts of questions that will be very tentatively explored here, with a strong emphasis on the questions regarding Malay. How did the inhabitants of the Indies know that they were speaking more than one language? Were they aware of it, at all, and even more: were they aware of differences between the two languages, or three languages they were using, and of their concurrent effectivity?

\section{Indies Society and its Heterogeneity}

The main argument in the following is simple: towards the end of the nineteenth century the segmentation which had divided the population of the Dutch Indies along lines of caste distinctions intensified; through authoritative words and actions, ethnic or racial divisons were gradually substituted for caste distinctions, and the heterogeneous Dutch Indies society turned into a society organized along lines of race.

From caste-based segmentation towards a race-based segregation: the process has been described in many ways, from many perspectives. Obviously, the Dutch masters played a predominant role in its initiation as well as its implementation; it led to a wide variety of reactions from Europeans and natives, as well as from foreign Orientals-and therefore to a strengthening of this segregation. An effort will be made to describe this development from the perspective of Dutch Authority, and, rather than doing this in sociological terms, ${ }^{9}$ the focus will primarily be on the changes in the Dutch attitude towards language. Two phenomena in particular will be discussed: first, the rise of Malay as the language of the

${ }^{9}$ See for this, e.g., Van Doorn, A Divided Society. 
"others"- or perhaps we should say the creation, or even the invention of Malay by the Dutch masters; second, the reflection of this linguistic segregation in Dutch texts that present themselves as literature-after all, since Du Perron and Nieuwenhuys wrote their authoritative books on Dutch Indies literature, it has been generally assumed that the majority of the so-called colonial novels are more effectively read as reflections of the mentality of the Dutch-speaking people in the Indies than as works of literary art. As Du Perron formulated it in his "Indies Memorandum": "In a colonial novel the typically Indies reader wishes to learn about conditions, and even more: to recognize such conditions"; in the wake of Du Perron's wisdom we may expect to find a wide variety of comments on this process of societal segregation in novels and short stories. Moreover, leaning on another of Du Perron's famous remarks- "in the Indies one has always cared less about literary talent than about the question whether the 'conditions' presented by the authors were true or not" - we can safely assume that the predominance of the theme of "confrontation between European and native elements" could serve as another illustration of how much the Dutchspeaking society was obsessed by segregation, and how much the leading groups of that society were intrigued by questions of color and caste. ${ }^{10}$

$* * * * *$

A suitable starting point could be the stay of Mr. and Mrs. Raffles in Batavia shortly after 1810. Their outrage could be presented as the metaphor of all the elements which set in motion an initially vague and uneasy awareness of a clear-cut identity among those who claimed to be of European descent. ${ }^{11}$ The British Lieutenant-General and his wife were among the first of a growing number of "baren" (newcomers) who were appalled rather than intrigued at the sight of the style of life which their fellow Europeans had adopted in the Indies. "Moral decline" they termed it, and, of course, an end had to be made to this behavior, which was so humiliating for the white race, so degrading for the predominant group. By confronting the local elite with the achievements of European technology and efficiency, by showing the moral superiority of the European nations, the British forced their fellow "Europeans" to reflect on their cultural identity. The members of this Indies elite were to be made aware of the fact that they had been granted Authority by Authority in the Motherland, and that that very Motherland wanted them to be distinctly different: a shining example to the backward "Malay nation" of how to work, how to behave, how to live.

Mrs Raffles tried to persuade the women of the Indies elite to refrain from using the cuspidor; from now on they should dress in a decently European manner, sit on a chair at a table, and eat with fork and knife. Mr. Raffles never stopped showing irritation at the way the government was run, and again and again he expressed his surprise at the defective knowledge of the local languages among Dutch civil servants:

\footnotetext{
10 "de typies-indische lezer wenst in een koloniale roman bovenal toestanden te leren kennen; nog liever, toestanden te herkennen," and: "Men heeft in Indië zich toch altijd minder bekommerd om literair talent dan om het al-of-niet juiste van de 'toestanden' door de schrijvers behandeld." E. Du Perron, Indies Memorandum, ed. E. Batten (Amsterdam: de Bezige Bij, 1946), p. 234.

11 A wonderful description of Mr. and Mrs. Raffles' stay in Batavia and much more can be found in Jean Gelman Taylor's The Social World of Batavia-European and Eurasian in Dutch Asia (Madison: University of Wisconsin Press, 1983).
} 
Hitherto the communication with inhabitants of the country has been chiefly through illiterate Interpretors, or when direct, through the medium of a barbarous dialect of Malay, confounded and confused by the introduction of Portuguese and Dutch. 12

The women in their lifestyle like the native elite of insiders, the men in their language usage like outsiders-on first sight, these may seem like two totally unrelated characteristics of the Indies' elite. Yet, it was only a contradiction on the surface; in actual life, they were two complementary features that, as Taylor showed, could very well go together as a distinctive and highly respected element in the heterogeneous society the Indies was at the time.

In the 1820s, Authority over the Archipelago was returned to the Dutch, who initially focused their attention on Java and the Moluccas but soon started to move to other islands as well. Operating in the intellectual shadow of Raffles, Governor-General Van der Capellen was fully aware of the fact that the Archipelago could not be governed by force of arms alone, and that Dutch rule could only be maintained by displaying the moral authority which placed the civilized European above the native. ${ }^{13}$ Civil servants should demonstrate (and feel) some sympathy for their subjects, and it was therefore ruled that the government official who showed himself proficient in one or more of the native languages would be eligible for promotion sooner than the civil servant who stuck to his Dutch Indies' Dutch and the Malay he had picked up, from his wife, his servants, his clerks. Secondly, some sort of Training College should be set up where candidate-officials were to be taught administrative techniques and languages so that they could then effectively demonstrate to the natives the moral authority of Europe: efficient, distinct, and sympathetic. These were the years when some language officials were appointed by the government in Batavia to study the vernaculars of the Dutch Indies, when Werndly's Malay grammar was republished, and Marsden's grammar and dictionary were translated and published on behalf of the government; when the desirability of the compilation of a new Malay dictionary was not only vehemently discussed but led to the assignment of some linguistic experts as well. The "scientification" of the colony had started-distance was created between administration and subjects, appropriate to scholarship but eventually unfavorable for the maintenance of sympathetic relations, as time would show.

This awareness of moral superiority and, concurrently, this feeling of having obligations towards the natives could easily be made the encompassing theme of a narrative on the Dutch administration of the Indies after Raffles' departure; it was to obsess Dutch brains and pens up to the 1930 Census and the Visman-rapport of 1942 in various forms. Initially it was a matter of paper and patience rather than of concrete action: those who arrived in the Indies in the days of Van der Capellen and Baud-the first half of the nineteenth centurywere still easily absorbed by "Indische" habits and customs. An authoritative and hence unifying center of culture was lacking in the Indies; most European males were not allowed or able to marry a European woman, so they took a Eurasian wife or a native concubine instead and then were pulled into the Indies life of rijsttafel, afternoon naps, and Malay. "Indiesization" (verindisching) was almost inevitable. Moreover, not all newcomers were as appalled by local habits as Mr. and Mrs. Raffles had been; often they adapted to the heterogeneous conditions of Java and beyond which tapped a vigor and vitality inconceivable in the Motherland. In this connection Ritter's praise of the Indies became winged words

\footnotetext{
12 See T. S. Raffles in "A Discourse Delivered at a Meeting of the Society of Arts and Sciences in Batavia, on the Twenty-fourth day of April 1813," in Verhandelingen Bataviaasch Genootschap 7 (1814): 13.

13 See C. Fasseur, "Leiden and Empire: University and Colonial Office 1825-1925," in Leiden Oriental Connections 1850-1940, ed. W. Otterspeer (Leiden: Brill, 1989), p. 188.
} 
indeed: "No matter where he was born, in the Indies a European is a completely different being than in the country where he saw the light of life."14

Such a positive remark should be complemented with some negative remarks from the same period: "A newly arrived Dutchman becomes daily more indulgent, he starts to whine in Malay, does not feel well ('lekker') in the morning, has himself massaged, and is sitting and lying in sarong and kabaay half the day (-) and is gradually pulled along by those liplaps' who usually do not know a single word of Dutch,"15 wrote Olivier, in one of the widely read travel books he published around 1830. And government officials? They were fogeys without much culture, "who, supported by betel-chewing nonnas, only knew how to express their thoughts in a sinjo-language and had no more education than daily affairs were teaching them."16

Now what did it mean to speak "sinjo language" or "Malay" in those days?

Since they first arrived in the Archipelago, European merchants and soldiers, missionaries and soldiers had used Malay in their contacts with the indigenous population. By doing this, they tied in with a long tradition in Southeast Asia. For centuries Malay had been used as a medium of communication among people of different origins; next to the forms of Malay that were used in the Malay heartland-the east coast of Sumatra, the Peninsula, and the west coast of Kalimantan-all sorts of Malay had come into use along the coasts around the Java Sea, the Malacca Strait, the Chinese Sea, and the seas east and southeast of Macassar, where Malay became so predominant that it succeeded in pushing its main competitor, Portuguese, aside.

Malay was the first local language into which the Bible was translated, but this Bible Malay was certainly not the Malay that was used by Moluccans and Menadonese, those who were most intenseively affected by the Dutch presence until 1870 . It was primarily based on the Malay that its initiator Leydecker had allegedly found in manuscripts that originated in the Malay heartland. ${ }^{17}$ Criticism of this so-called "High Malay" (Hoog Maleisch) of the Bible would not die down-and only in a very abstract manner did it serve the Company as a compass in its letters and communications with local rulers and merchants.

In his authoritative book on Malay, published in 1812, translated into Dutch in 1824,18 and almost obligatory reading for civil servants in the Dutch Indies around 1830, the British scholar Marsden observed that the Malays themselves hardly ever used the term "Melayu"

14 "een Europeaan waar hij ook geboren moge zijn is in Indie een geheel ander wezen dan in het land waarin hij heerste levenslicht aanschouwde." See, for example, in R. Nieuwenhuys, Oost Indische Spiegel (Amsterdam: Querido, 1972), p. 13.

15 "Een pas aangekomen Hollander)wordt van dag tot dag trager, begint Maleis te temen, bevindt zich 's morgens niet lekker, laat zich pidjiten, en zit of ligt de halve dag in sarong and kabaai (-) en wordt meegesleurd door liplappen die dikwijls geen Nederlands kennen." See J. Olivier, "De levenswijze der Europeanen," in Wie verre reizen doet, ed. R. Nieuwenhuys (Amsterdam: Querido, 1975), p. 105.

16 "die bijgestaan door sirih pruimende nonna's, slechts in sinjo-taal gedachten wisten uit te drukken, en dus cok overigens geen andere ontwikkeling hadden dan de dagelijkse bezigheden hun aanbrachten." Cf. Van der Kemp, "Het herstel van het Nederlandsch gezag in de Molukken," in Bijdragen tot de Taal-, Land-en Volkenkunde 65 (1911): 563.

17 See J. L. Swellengrebel, In Leijdeckers voetspoor-anderhalve eeuw bijbelvertaling en taalkunde in de Indonesische talen I (The Hague: Nijhoff, 1974), pp. 13-18.

${ }^{18}$ See W. Marsden, A Grammar of the Malayan Language, with an Introduction and Praxis (London: Cox, Baulis, and Marsden, 1812) and its Dutch translation by C.P.J. Elout: W. Marsden, Maleische spraakunst, uit het Engels vertaald door C.P. J. Elout (Haarlem: Enschede, 1824). 
to refer to themselves. Only "other" people did so, and those people were the very ones who made use of forms of Malay, called "bahasa dagang" (bazaar Malay) rather than of forms that were used in the Malay heartland-European immigrants and merchants, for instance. Equally noteworthy is Marsden's claim that the inhabitants of the East Indies in general did not have a clear concept of race and language but, instead, regarded religion and adat as the most relevant criteria in defining their own group and distinguishing it from "the others." $A$ solid child of the Enlightenment, Marsden was a very keen observer; many remarks to this intent can be found in his work which altogether create a strong suggestion that people on the islands did not have a strong awareness of borders and frontiers.

Of course, this is not to say that conflicts and tensions were not many and varied, but tolerance, flexibility, and the will to assimilate and associate were always there, out of practical considerations, out of indifference, or out of opportunism. Insofar as the Europeans were accepted as the leaders of society, this usually happened in close cooperation with the local rulers who made it possible for them to be sufficiently accepted by local communities. Or to put it differently: they managed to play the game according to local rules. "Segmentation was recognized as a fact of life and no one expected any significant measure of integration to occur in the foreseeable future." ${ }^{19}$ Differences were not necessarily felt to function as strict borders. It was a mixed and fragmented society, in ethnic, linguistic, and cultural terms, a confusing network of groups and castes held together by a certain degree of tolerance and indifference.

"A heterogeneous society" may be an equally appropriate term here: a loose network of differences and tensions that exist wherever people are forced to live together, in the shadow of a center that is strong enough to impose some kind of political and economic unity but too weak to impose a distinct cultural hegemony and produce a well-defined ideology to express it. The description that Rob Nieuwenhuys gives of this heterogeneity of the "European community" may apply to the Indies as a whole (first Java, later other islands as well), albeit with many nuances and variations:

The merely superficial contacts, the need of self-glorification, the defense of the newly acquired attitude and prestige; in general terms: the heterogeneity of society. In addition to this, there was no awareness of a common culture, no distractive interest in spritual matters, no strict family ties, no 'esprit de corps', nor even the uniting feelings of class. ${ }^{20}$

Operating from the top of this heterogeneity, Europeans may have been as ignorant of the "real Malay" as spoken by the people in the Malay heartland as was every other contemporary group of rulers and traders in the Indies. Just like "the others," they used dagang or kacukan varieties of Malay in their contacts with the local population whenever the situation called for it. Already in Marsden's days, linguistics tended to present these spoken forms as "impure" and "incorrect" forms, against the background of the vague notion of a standard that could be found in the written Malay as transmitted through manuscripts and reflected in the Bible. In modern terms, these spoken forms of Malay could be called "pidgin" - of a

\footnotetext{
19 Van Doorn, A Divided Society, p. 6

20 "het slechts oppervlakkige contact, de behoefte tot zelfverheffing, de verdediging van een nieuw verworven houding, van het prestige, in het algemeen: de heterogeniteit van de samenleving. Hiertegenover stonden geen gemeenschappelijk cultuurbesef, geen afleidende geestelijke belangstelling, geen hechte familie-banden, geen 'esprit de corps' en ook niet het bindende standsgevoel." See R. Nieuwenhuys, "Over de Europese samenleving van 'tempo doeloe' 1870-1900," in De Fakkel 1 (1940): 793.
} 
simple linguistic structure, almost no redundancy, without a clear standard, but sufficient for communication between people who had a better knowledge of another "language." 21

People on Java - in the nineteenth-century, the Indies' central point of reference for the Dutch-used these pidgins of "Malay" next to forms of a "language" that they thought, no matter how vaguely, to be supported by a certain set of cultural values, customs, and religion: Javanese, Sundanese, Madurese, Dutch, French German, Balinese, Batavian. Very heterogeneous indeed. In part due to the influx of Chinese, who had the same problems of communication as the other merchants and bureaucrats, these pidgins slowly organized themselves around models and became the first-learnt tongue of a growing group of inhabitants in the coastal areas where most of the Europeans were living or had their contacts.

Until 1860, neither the natives in the coastal cities and beyond nor the great majority of "Europeans"-a loosely organized and heterogeneous group of people who had a more or less solid knowledge of Dutch, French, German, or English, and often a knowledge of more than one of these-were very much aware of the linguistic problems that visitors from Europe were so derogatorily pointing at. "We can say what we want," the argument ran, "and we may express ourselves differently, yet we are perfectly understandable, and somehow they manage to make themselves understandable to us, and for the rest we keep to our own language."

"Malay" was very easy to learn, so the myth ran among the Europeans. If necessary it could be learnt on the boat to the Indies, or else a couple of weeks in the Indies were sufficient to order servants and clerks around. "In case you do not know the Malay word, just say it in Dutch, French, or German-and everybody will understand." Wherever the Dutch Indies Government had established their hegemony beyond the Malay heartland, some people could be found who were familiar with Malay even though effective reading and writing expertise was rare in those days. Often enough, local administrators and rulers made use of clerks and translators, those unreliable transformers of language.

This attitude towards language could very aptly be described in Bakhtinian terms: a complex interaction of utterances, discourses, speech-genres, "languages" 22 which-far from being unitary, far from circling around generally accepted centers of authorityformed a continuum of mostly spoken forms, in a number of not very clearly defined domains and a great amount of variation. A slippery continuum, that is, a continuous switching between codes and styles. In the Indies, linguistic differences were great no doubt but they were not felt to be unsurmountable; nobody was able to give an exact definition of how the system worked, and yet most people managed to maintain themselves in it. Somehow

21 These discussions find an echo in the conversations among twentieth-century Dutch linguists about the distinction between Malay as a language of culture (cultuurtaal) and a language of communication (verkeerstaal); interestingly enough, these conversations hardly ever addressed the question of how the variations of the two could still be categorized under one and the same term.

22 This is what Bakhtin tells us, every time in a new formulation: in actual social life, "language" does not have clearly defined barriers, it does not operate within a sealed-off system. "It is unitary only as an abstract grammatical system of normative forms, taken in isolation from the concrete ideological conceptualizations that fill it, and in isolation from the uninterrupted process of historical becoming that is characteristic of all living language." If "language" is the term to refer to the concrete and ceaseless flow of utterances produced in dialogues between speakers and writers in specific social and historical contexts, it could be asked whether the very term does not lose all its effectiveness when we try to give a careful description of the discursive interactions that were taking place in the Indies. Centrifugal forces were strong; there was "no single plane on which all these Janguages' were juxtaposed to one another." See M. Bakhtin, The Dialogic Imagination-Four Essays, ed. M. Holquist (Austin: University of Texas Press, 1981), in particular pp. 288-95. 
differences did not really matter. Somehow things worked to the satisfaction of all of those involved. Call it linguistic co-existence, acceptance, appreciation. Call it heteroglossia, parallel to Nieuwenhuys' characterization of Indies society as a heterogeneous society: "representing the co-existence of socio-ideological contradictions between the present and the past, between different epochs of the past, between different socio-ideological groups in the present, between tendencies, schools, circles, and so forth."

Heteroglossia constantly has difficulty in maintaining itself; it is always running the risk of being curbed by some hegemonic center which is able to forge societal and linguistic forces in such a manner that centripetal forces gain the upper hand over the centrifugal ones. In the process, prestigious forms of discourse try to extend their control while subordinated forms of discourse try to avoid this control. ${ }^{23}$ In the Indies, there were forms of what we now call "Malay" -commercial transactions and administrative discussions, law books and text books-that were able to gain some kind of control, to assimilate speech genres of other "languages," even so far that in the second half of the nineteenth century the forms of Malay that were used beyond the heartland were tentatively taking the shape of a language in its own right.

In came the Dutch totok, the Mr. and Mrs. Know-it-all from Holland, people who, like Mr. and Mr. Raffles before them, showed their contempt of the cultural anarchy they saw around them, and called the way people expressed themselves "gibberish." The totok had been coming in ever since Raffles, but only when the Indies were opened up to capital investment did their number increase fast enough for their voice to be heard. The leaders of these newcomers had been educated in Delft and Leiden, often by so-called scholars who had never been in the Indies themselves. They started to dictate how the colony should be run, how offical letters should be written, how language had to be used, how natives should be treated. A nuisance indeed to the "oudgasten."

I give you the solemn assurance that I have come to know many young men from Delft who could be called clever boys in comparison with officials who worked on the basis of their experience; but I also met many youngsters who ruined all the good things which education had brought into them by showing a certain pedantry and self-glorification. The empiricists may have been rough, ill-mannered and self-willed towards the less rough but more experienced and often more civilized natives, yet our young Delftians showed themselves to be proud and distant, and not seldom so arrogant and big-headed that they refused to appreciate anything which had not been sucking at the maternal breast in Delft. ${ }^{24}$

These were the young men who introduced the "real," the "correct" Dutch language, modeled on Hildebrandt and Tollens, the young women who wanted to introduce and defend "Dutch culture." Operating in the shadow of the imperial adventure, awareness grew that the bureaucratic machine could not but expand, unstoppably, inevitably, and that European

\footnotetext{
23 See Alon White, "Bakhtin, Sociolinguistics and Deconstruction," in The Theory of Reading, ed. J. Gloversmith (Brighton: Harvester, 1984), pp. 124-25, 132 , and 136.

24 “Ik kan $U$ de heilige verzekering geven, dat ik vele jonge mannen uit Delft heb leeren kennen, welke men tegenover de vroegere op ondervinding steunende ambtenaren, knappe jongens moogt noemen; maar ik heb er even vele ontmoet die door zekere waanwijsheid of zelfvergoding al het goede bedierven, dat de opvoeding in hen had weten te leggen. Waren de empirici ruw, onbeschoft en eigenwijs, tegenover de minder ruwe, maar aan ondervinding rijke, ja dikwijls meer beschaafde inlanders, zo toonden zich onze jonge Delftenaren trotsch en afwerend, en niet zelden zo verwaand en ingenomen met zichzelven, dat zij niets voor goed bechouwden dat niet gezogen had aan moeders borst, te Delft." F. C. Wilsen, Lain doeloe, lain sekarang of Voorheen en thans (Amsterdam: Meijer, 1868), pp. 364-65.
} 
officials were needed to keep that machine running in close cooperation with native underlings. The Regeringsreglement of 1854 stated it clearly: the government had the obligation to provide all Europeans (and those who were given the same status) with education and to create educational facilities for the native population as well. With respect to the Europeans, the 1930 Census showed that the policy had been reasonably successful, witness the 75 percent literacy among them; with respect to the native population, facilities remained scarce until the very end of the colonial period, witness the 6 percent mentioned in the Census. The possibility that the natives' curiosity for European accomplishments could be sincere and without immediate political or egotistical motives was never seriously taken into account. ${ }^{25}$

Education was started, no matter how limited. The planning and publishing of textbooks was initiated, no matter how selective, not only in Dutch but also in the local "languages," Malay most of all. In the wake of print, the awareness that a standardization of the languages of the Indies was needed soon emerged-concurrent with the feeling that languages should be clearly distinguished and categorized.

Administration and literacy, education and print: they are conducive to discursive uniformity in every community no matter how heterogeneous, and the Dutch Indies was no exception to this rule. "Batavia" managed to maintain its hold over centripetal forces; control had to be strengthened and that implied integration, standardization, uniformity in every field of life. Cultural plurality and linguistic flexibility were subverted, and differences and distinctions in customs and tradition were increasingly defined in terms of language. Scholarship wanted order, constructed grammars and dictionaries-and concepts like borders and restrictions were introduced. Cultural definition and societal segregation were the result. Heteroglossia was transformed into polyglossia.

Authority, on the one hand, stimulated Europeans to use "correct" Dutch: utterances, speech genres, styles that were dominated by what was regarded as "Dutch" had to follow the standard Dutch of the Netherlands as much as possible. Eventually, it was assumed, a "Dutch dialect" would come into existence, on a par with the dialect of Groningen or Den Bosch-and that is the kind of Dutch, we may assume, that 75 percent of the European population used for their compass in 1930 . On the other hand, Authority stimulated the standardization of what they considered to be the various vernaculars. Initially two languages were at the top of the agenda: Javanese, the language of the majority of the Indies populaon, and Malay, the main language of contact in the Indies. After some ineffective efforts to carve out a place for Javanese in the brains of the administrators, from 1860 onwards the main focus was on Malay. Once the Dutch started to spread their influence from Java to other islands where they expected to find even more bewildering varieties of pidgin Malay than in Java, the need to construct a standard Malay-to-be was more urgently felt than ever before-for the sake of an effective bureaucracy, a successful army, a profitable economy. ${ }^{26}$

\footnotetext{
25 See, e.g., J. Brugmans in Geschiedenis van het Onderwijs in Nederlandsch-Indie (Groningen: Wolters, 1938 ), p. 242. Of course this is a simplification; special mention should be made, for instance, of the activities of the various mission associations. They played an important "civilizing" role in the nineteenth century, by way of their schools, their publications in local languages, their teaching materials, their interest in local languages, customs, and religions; see on this subject e.g. the fascinating books of H. Kroeskamp, Early Schoolmasters in a Developing Country (Assen: Van Gorkum, 1974), and S. C. Graaf van Randwijck, Handelen en denken in dienst van de zending (The Hague: Boekencentrum,1981). As for the teaching in Dutch: see the excellent survey of Kees Groeneboer, Weg tot het Westen-Het Nederlands voor Indie 1600-1950 (Leiden : KITLV, 1993).

26 For this and the following see the excellent essays of Kenji Tsuchiya, "Javanology and the Age of Ranggawarsita: An Introduction to Nineteenth-Century Javanese Culture," in Reading Southeast Asia (Ithaca: Southeast Asia Program Translation Series, 1990), pp. 75-108, and John Hoffman, "A Foreign Investment: Indies Malay to 1901," Indonesia 27 (April 1979): 65-92.
} 
Changing circumstances forced Batavia and The Hague to formulate a resolute answer on a question that had been bothering European magistrates ever since the center of their activities moved from the Moluccas to Java in the course of the eighteenth century: which kind of language had to be used for a strong and centralizing force? A definite answer had never really been formulated, but, of course, the forms of discourse that were regarded as forms of "Malay" had always scored high in these discussions. Maybe the Hoog-Maleisch some Dutch officials had learned to use both in speaking and writing on the basis of their pious knowledge of the Leydekker Bible translation was the most effective form. Maybe it should be based rather on that provisional kind of Malay called "Dienst Maleisch," with which so many people in the Indies, European, natives, and foreign orientals alike, were familiar. ${ }^{27}$

Until late in the nineteenth century, wide acceptance of Malay was still complicated by an occasional plea in bureaucratic circles in defense of Javanese, and even of Dutch. Baud had been the fiercest and most tenacious advocate of the first of these alternatives to Malay. He was the one who had seen to it that the "Instituut voor de Javaansche Taal" was set up in Surakarta, and when this turned out to be a failure he managed to convince his superior, King William II, of the necessity of using the newly established Delft Royal Academy for Engineers to train prospective East Indian officials, and have Javanese taught there as the most important language. From his own experience in the Indies, Baud knew that hardly any Dutch civil servant knew Javanese and preferred to make use of some kind of "patois" which, the Secretary claimed, was not understandable among the local population and certainly did not enhance mutual sympathy and respect. ${ }^{28}$

In Delft, however, Javanese was also unsuccessful, despite the support of minister Baud, and despite the serious efforts of the widely respected linguist Roorda who, out of professional interest it seems, tended to give Javanese priority over Malay. Teaching a language presupposes the availability of a good grammar book and a solid dictionary; the composition of those two presupposes a careful study of the language, and sooner or later a conflict will arise between practical activities and scholarly reflection. Roorda was too much of a scholar: the civil servants who had been taught Javanese for three or four years in Delft were to discover in Java that their knowledge of the language was far from adequate to deal with the local population and their rulers, and sooner or later they, too, moved to Dienst Maleisch. Baud, a man of experience and insight, was already aware of this in 1842. Some years later his friend and ally, Governor-General Rochussen, decided to make Malay the language for dealing with local rulers - the more Authority had to cope with rulers outside Java the wiser this decision turned out to be.

Baud may have failed to put Javanese in the limelight, but he certainly succeeded in his plea for establishing a special institution for training Dutch civil servants. The Dutch Indies administration should be set to govern the peoples of the Indies in fairness and justice, and, above all, in deference to native attitudes, customs, and biases. In accordance with this idea, Baud and his political friends had the firm conviction that a colony could only be effectively

27 The term, Dienst Maleisch, itself covered a wide variety of forms, serving all parties involved in the colonial dialogue of exchanging information and letters in a way that did little to harm or humiliate those involved. See on this C. Grijns, "Bahasa Indonesia avant la lettre in the 1920s," in Papers in Austronesian Linguistics, Series A-81, 1991 (ed. H. Steinhauer), pp. 49-81.

${ }^{28}$ For this, see C. Fasseur's exciting monograph, De Indologen: Ambtenaren voor de Oost 1825-1950 (Amsterdam: Bert Bakker, 1993). 
run by administrators with a good local knowledge, which should include the learning of native languages. ${ }^{29}$

In this spirit, a series of half-failed, half-successful institutions were experimented with in the course of the nineteenth century: a school in Solo; a training school in Delft; a governmental institution in Leiden (from 1864); a special division at the Batavia Gymnasium Willem III (from 1867); another institution in Delft (from 1864); and yet again a firm place within Leiden University in 1877, this time more scholarly than practical as opposed to the Delft institution-so that prospective civil servants preferred to attend Delft and were to cause much annoyance to those who had been in the Indies for generations. Opheffer's fury is exemplary, an echo of Wilsen's complaints fifty years earlier:

According to which regulation can you do this? Is this not in conflict with the Regulations, Supplement sub 748 ?

That is the main error these days. Interest for Kromo, the common man, is nowadays a sign of degeneration, a sign of indiesization, a sign that you lack a broad vision. You are supposed to be active in the field of law-making, to formulate proposals in order to change ordinances-only in that way can you prove yourself competent. ${ }^{30}$

Delft had to close its doors in 1900 . From then on, The Hague's policy was aimed at making Leiden University the place where those who wanted to join the Indies civil service had to be trained. Teaching candidate administrators was gradually reformulated in a mold where Minerva ruled superior. There was a strong awareness among leading bureaucrats that the administration of the Indies could not but expand and that this expansion required civil servants who combined an acute understanding of what was going on in colonial life with intellectual and administrative rigor, so that daily routine could be left to indigenous, locally trained administrators who were cheaper, more knowledgeable, and, if well-treated, very loyal. A solid knowledge of Malay and/or other native languages was considered indispensable as a general intellectual training. Genealogically speaking a product of Baud's vision, but effectively the result of Snouck Hurgronje, "Indology" was created, a fully fledged scholarly discipline in which a careful equilibrium was observed between economics and administrative law, on the one hand, and a good knowledge of indigenous languages, on the other. Malay was made a compulsory subject and, apart from Javanese, a number of other local languages (and their literatures) were incorporated in the curriculum.

Judging from textbooks, law books, and other materials that were used, it was mainly forms of High Malay that were taught over there in Holland. The Malay of manuscripts and official letters, very decent, very difficult. No wonder these civil servants had problems in understanding the Malay that the natives used when they met on their official and unofficial tours through "their" regions, dressed up in their impeccably white uniforms and surrounded by an aura of efficiency and sympathy. These were the very same problems with which their less well-prepared predecessors had been confronted, but they were now tackled with a slowly changing lifestyle-more formal, more urgent, more imposingthanks to their Dutch wives who were dreaming of Dutch culture.

\footnotetext{
29 See C. Fasseur, "Leiden and Empire," pp. 187-203.

30 "Volgens welke bepaling mag je dat doen? Ben je niet in strijd met Bijblad No. 748? Dat is de grote fout tegenwoordig. Belangstelling voor Kromo is tegenwoordig een teken van degeneratie, een teken dat je verinlandscht bent, een teken dat je een breeden blik mist. Je moet op wetgevend gebied werkzaam zijn, voorstellen om ordonnaties te verbeteren, dan pas geef je bewijzen van bekwaamheid." Opheffer, Brieven van Opheffer aan de redactie van het Bataviaasch Nieuwsblad (Maastricht: Leiter-Nypels, 1911), p. 92.
} 
As a whole, the educational apparatus that arose in the Indies was an effective tool in the hand of authorities in Batavia, an extension of developments in colonial thinking in the Motherland. Soon enough the Dutch masters were to realize that education was needed to get the colony organized and would be of great help in gaining control over discourses, in imposing a certain ideology. Sooner or later, all educationalists were aware, more or less explicitly, of the help education could offer to "ritualise speech, fix the roles for speaking subjects, constitute a doctrinal group, however diffuse, distribute and appropriate discourse with its powers and knowledge." 31 Primary teaching was given in the vernaculars as well as in Dutch, more advanced teaching mainly in Dutch and Malay; the serious flaw in this ritualization of speech, however, was the uncertainty which Authority continued to have about what kind of Malay should be imposed, and how to impose it effectively as a unifying motor.

\section{The Study of Malay}

John Hoffman has already pointed out that an "important catalyst in the movement towards standardization of Malay in Western script was an amalgam of philology and a growing consciousness of an Indies identity such that a 'ingua franca' justification for Malay had become insufficient." ${ }^{22}$ Philology and the concept of a "correct" Malay language: those two concepts usually go hand in hand. Malay had to be studied and analyzed so that a single form emerged which was strong enough to homogenize and centralize the complex variety of utterances and become the authoritative substitute for the wide variety of dialects and sociolects that had ruled colonial discourse for so long. Malay was scientificized, so to speak, and, of course, this led to fierce and bitter conflicts among scholars, administrators, and educationalists - if only because nobody was able to define Malay and set a standard for its description, and everybody tended to talk from his own experience and knowledge.

As the result of the pleas of respected "philologists" like Klinkert and Van der Tuuk in particular, some consensus was reached among those who were in the position of advising the government what the correct Malay was and how it should be taught to the subjects of the Dutch Indies: basically it was to be the Malay of the Malay heartland of Riau and Malakka. The original Malay, the real Malay was to be found in the cradle of Malay culture, and the forms outside of it were considered deviations, deformations, and impure. Equally noteworthy in this connection is the strong preference which Klinkert and Van der Tuuk showed for written Malay over spoken Malay: it was thought to be more pure, more real, more direct.

That is how, in the 1850s, the amateur linguist von de Wall was sent to Riau to collect materials for compiling a standard Malay dictionary, the revitalization of a project that had been initiated in the time of Van der Capellen, which itself had been a revitalization of a project started by Leydecker, Werndly, and Van der Vorm in the first half of the eighteenth century. While von de Wall lived in Tanjung Pinang, made contacts with local scribes, and sent out clerks, Van der Tuuk and Klinkert published a series of scathing and scorching criticisms of the Malay textbooks that the government had published in anticipation of von de Wall's findings and that had been the first serious attempt to standardize the Malay offered in the curriculum of the expanding educational apparatus. The government should

\footnotetext{
31 See Michel Foucault, "The Order of Discourse," in Untying the Text-A Post-Structuralist Reader, ed. R. Young (Boston/London: Routledge \& Kegan Paul, 1981), p. 64.

32 See Hoffman, "A Foreign Investment," p. 77.
} 
be more careful, more thoughtful, and wiser, was the philologists' warning; it had to show the natives the pure, correct, and best Malay-and how on earth could this be found in places like Batavia or Menado, as so many textbooks seemed to suggest, instead of in Riau and the Malay heartland?

Of course Van der Tuuk and Klinkert, in their turn, invited criticism from those who did not operate in the Malay heartland but in Batavia, Menado, or Fort de Kock, who had become familiar with local varieties of Malay there, and were unwilling to consider the introduction of Riau Malay as "the" standard to be self-evident. "The momentum of Malayization," as Hoffmann calls it, was never to lose its force again, but this force was never made concrete: the implementation of Malay remained a dilemma. The actual situation was to remain vague, retaining much of the very heterogeneity Authority tried to eliminate.

Forty years after the introduction of the new Regeringsreglement of 1854, the situation of Malay had not yet really changed. Van der Tuuk had published a summary of the materials von de Wall had collected in Riau. Klinkert had published yet another Malay-Dutch dictionary and was no longer a close companion of Van der Tuuk. Scholars like Pijnappel, Gerth van Wijk, Klinkert, and Spat had published grammars and textbooks of all sorts, for different kinds of people. But the Europeans were still using "gibberish Maleis," even those who had been taught High Malay in Delft and Leiden. The natives were still using their own vernaculars. The population on the coasts of the Eastern Seas were still using a wide variety of Malay to one another. School books still offered a variety of forms of Malay. And the Malay translations of Dutch regulations and laws were as loose and incomprehensible as ever before-if they were even made. The centralizing force had been created, the awareness was implanted, but heterogeneity was not yet under control.

In 1870, Busken Huet-journalist, man of letters, reverend-gave some hilarious examples of the linguistic situation in the Indies in a public letter to an (imaginary) Dutch linguist who did not appreciate Indies' discursive heterogeneity and felt compelled to complain about the quality of Dutch in the Indies; the end of the letter reads like a summary of the linguistic knowledge among Europeans:

So you see, Mr. Know-it-all, that it is possible to talk about a wide variety of Indies things with a very restricted vocabulary, about serious as well as funny things, and in this one does not at all feel the need of the wealth of your European languages. Among ourselves (-) the optative "soeda" would do, and in our relation with the native population I would be greatly surprised if all points of contact with them could not be summarized in an appropriate manner by the imperative "kassie." 33

The irony befits Busken Huet but the message is clear: some command of Malay sufficed for the masters. Indeed only a few Europeans took the trouble to go deeper into it; for most of them there was no point in making a point of it. Operating in the shadow of homogenizing efforts undertaken from above, it seemed it was not really necessary to accept a thorough command of Malay in the ongoing heterogeneity of everyday life.

\footnotetext{
33 "Zoo ziet gij, mijnheer de wijsneus, dat men met een zeer beknopt vocabulair over zeer verschillende Indische zaken praten kan, ernstige en vrolijke, en daarbij aan den rijkdom uwer Europesche talen allerminst behoefte gevoelt. Onder elkander (-) zouden wij desnoods met het optatieve soeda kunnen volstaan, en wat onze betrekking met de Inlandsche bevolking aangaat, mij zou het verwonderen, zoo al onze punten van aanraking met haar, niet gevoegelijk op dezelfde wijze in het imperatieve kassie konden zaamgevat worden." See C. Busken Huet, Tijgergenoegens (Amsterdam: Synthese, 1986), p. 116.
} 
"If I can only reach the stage at which I can give them a sound reprimand in Malay,"34 muses the heroine about her attitude to her servants, in a novel by Adinda first published in 1892. And she has a friend, the narrator tells us somewhat uneasily, "who knew enough Malay to deal with the servants in practical matters; she lost her way however when they came to her with their stories and eventually she did not understand a syllable of them." This was apparently not really a problem.

Heteroglossia pervaded discourse in spite of the official policy of stimulating the idea of a "correct and good Malay" and regulating the use of Dutch. It haunted scholarly oriented administrators or administratively oriented scholars like Snouck Hurgronje, Advisor to the Government. The administration was to become increasingly complicated, Snouck did not stop remonstrating to his superiors in Batavia as well as in The Hague, and Malay should therefore be standardized in order to decrease the misunderstandings which would all too easily emerge in schools and offices, in newspapers and books. Smooth ruling of the colony should be stimulated; and to that end, the language situation really should be changed, education really should be improved. Snouck stressed this point again and again: the text books that were used lacked uniformity, regulations and rules that were being issued in Malay translations were really incomprehensible.

Speaking from a similar uneasiness, Van Ophuysen in his inaugural lecture as Professor of Malay in Leiden in 1904 was keen to admit that "our knowledge of that language is not commensurate with the long period of time in which it has been studied and the great number of its students." 35 A fine appraisal of the state of the art indeed.

The role of Van Ophuysen was of crucial importance in view of the efforts to standardize Malay-in view of the invention of Indies languages in general. Partly due to the suggestion of Snouck, he had been given the assignment of compiling a list of Malay words in a systematic (European) spelling as well as of constructing a Malay grammar; those two books should serve as a definite compass for all officials and educators in the Indies as well as in the Netherlands. Standing on the shoulders of Klinkert, Van der Tuuk, and all those others that together made up "the great number of students," Van Ophuysen was of the opinion that the best and real Malay was used in what was generally seen as its land of origin, the Alam Melayu, the Malay heartland, the areas around the Strait of Malacca. The projected "algemeen beschaafd Maleis" was, just like the "algemeen beschaafd Dutch," to be primarily based on written texts, an assumption that for Snouck Hurgronje was as selfevident as it was for Van Ophuysen himself, and where could written Malay be found if not in the Malay heartland? Those were the areas Van Ophuysen visited on his study tour, and there he collected the materials he thought he needed. In retrospect, it is rather amazing that this great scholar did not have the slightest hesitation in assuming that the best and most correct Malay was used in the Malay heartland rather than anywhere else. Maybe even more amazing is to see how, after he had always laid so much emphasis on the importance of oral traditions and spoken forms of language, he now based the standard Malay on the written forms of Malay he found in Riau manuscripts rather than on the conversations he had with the local population.

\footnotetext{
34 "Als ik maar eenmaal zoover ben dat ik ze eens een flink standje in het Maleisch kan geven" and "zij kende wel genoeg van het Maleisch om zich in 't dagelijks leven met de bedienden te behelpen, doch zoodra ze met hun verhalen aankwamen, raakte zij den draad kwijt en verstond er ten slotte niets meer van." See Adinda, Vrouwen lief en leed onder de tropen (Schoorl: Conserve, 1986), p. 84.

35 "onze kennis van die taal is niet geëvenredigd aan de lange tijd gedurende welke zij is bestudeerd en het groote aantal harer beoefenaars."
} 
The argumentation that Van Ophuysen used in public in defense of his method of creating a new kind of Malay is a curious one, and worth a long quotation from the short introduction to his authoritative grammar of 1910:

In our country a variety of dialects can be found which show considerable differences; their influence even on the language of the cultured people cannot be denied. Yet we speak of one Dutch language and regard it as the language of the Dutch people as a whole. The same holds for Malay. Among the various dialects, Malays themselves-and after all, they are the only qualified judges-tend to give preference to the dialect that is spoken in Johor, a part of Malacca, in the Riau Lingga Archipelago. This so-called RiauJohor Malay in which the greatest part of the literature is presented will be treated in this book. (-) High Malay is the language which is spoken and written by the Malays, Low Malay is a patois that is formed from sentences that consist of words that are Malay or are regarded as such but which are put together without taking Malay idiom into account or, rather, by violating it. ${ }^{36}$

Spoken Malay? Written Malay? During his travels through the Malay heartland, Van Ophuysen, too, must have detected enormous discrepancies, not only between the way Malay was spoken and the way Malay was written but also among, respectively, the spoken forms and the written forms of Malay - the Malay of a little village in Kedah was different from the Malay that Van Ophuysen may have heard in Siak Indrapura, and the language of a Muslim treatise was definitely different from the language of, say, the Hikayat Merong Mahawangsa. Like everyone else he, too, must have wondered what Malay was all about.

The result of Van Ophuysen's endeavor was a new standard, a form of Malay with which everyone was unfamiliar. Dutch Authority was gaining sufficient hegemony, however, to make a serious effort to introduce "Van Ophuysen-Malay" in the educational apparatus of the natives. Eventually it was to be the victory of one dialect over the others, and in a wider sense an effort at "supplanting (other) languages, their enslavement, the process of illuminating them with the True Word, the incorporation of barbarians and lower social strata into a unitary language of culture and truth." 37

This is not to say that the introduction of the "Van Ophuysen-Malay" and the centripetal forces it embodied made an immediate end to Indies' heteroglossia. It provided no radical break, but a long-term project to homogenize and unify Malay, part of a wider effort to create an awareness of standardized language in a network of schools where a small part of the local population was taught to read and write in order to be given authority among their own people. Teaching materials may have differed considerably, but altogether Dutch educationalists followed the procedure advocated by Snouck Hurgronje in his advice to the Directeur van Onderwijs, Eeredienst en Nijverheid in Batavia:

36 "In ons land worden tal van dialecten aangetroffen, die onderling belangrijk verschillen, en waarvan de invloed, zelfs op de taal der beschaafden, vaak niet te miskennen is. Toch spreken wij van eene Nederlandsche taal en beschouwen die als de taal van het gansche Nederlandsche volk $(-)$ Zoo is het ook met het Maleisch. Onder de verschillende dialecten wordt door de Maleiers-en dezen zijn toch de eenig bevoegde beoordeelaars-de voorrang toegekend aan dat het welk in Djohor, een deel van Melaka, in den Riau-Lingga Archipel (-) gesproken wordt. Dit zoogenaamde Riau- of Djohor-Maleisch waarin een groot gedeelte der litteratuur is gesteld zal in dit werkje worden behandeld. (-) Hoog Maleisch (is) de taal door Maleiers gesproken en geschreven en Laag Maleisch (-) een taaltje gevormd uit zinnen bestaan uit Maleische of als Maleisch beschouwde woorden welke zonder reekening te houden met het Maleisch taaleigen, of nog vaker met verkrachting daarvan zijn samengevoegd." See J. van Ophuysen, Maleische Spraakkunst (Leiden: Van Doesburgh, 1910), p. 3.

37 See M. Bakhtin, The Dialogic Imagination, p. 271. 
The phrase "people's education should be given in the people's language" does not really help. One needs a conventional reading and writing language and wherever such a language is already in existence it can be taken over and changed where necessary (-) It should be realized that people's education, far from strengthening the position of the wide variety of people's languages and dialects, has made an important contribution in partly melting them together, partly making them disappear. It lies in the character and aim of this educational system to strive for a centralization and distribution of the knowledge of a single tool of spiritual community over as wide an area as possible. ${ }^{38}$

Parallel to the development of instructional equipment in Malay, text books in Javanese, Sundanese, Madurese, etc. were published and distributed-with the similar effect of standarization and unification. ${ }^{39}$ Centripetal forces were gaining the upper hand, becoming, in short, strong enough to shape a true center of authority but not strong enough to make an end to the discussions about colloquial and literate Malay, about Low and High Malay, and about high and low forms of other languages. Initially these discussions were held among the Dutch alone, over the heads of the very people who knew Malay better than most of these Dutch themselves but had to leave the hegemony of their language to their colonial masters. The assumptions and presuppositions of these masters are as interesting as the arguments themselves; the same could be said of the opinions and ideas the natives themselves were to bring forward on the subject. For everybody it was obvious that the road to unification could not but be a long one. Even Dutch authorities, usually so self-confident and cool, had their moments of doubts, to put it mildly.

"No language has been so affected by the desire for a system as the Malay language, for the very reason that there is hardly any system in it. People think it is an easy language-the number of unqualified students sufficiently shows this-and yet so far none of these students has succeeded in making it clear,"40 Van der Tuuk complained in the 1870 s. These became winged words in defense of the dismay felt by generations of linguists about their inability to get this "Malay" under control. They were quoted again and again in writing and speeches. We find these words, for instance, in Van Ophuysen's inaugural lecture of 1904 , and in the article by Hooykaas in 1939 which should be read as the conclusive testament to Dutch failures to understand and standardize Malay.

Seventy years of scholarship, three generations of scholars and administrators had not changed the validity of Van der Tuuk's complaint, and Hooykaas seemed perfectly willing to admit it-no doubt with a wicked smile. In 1930, the year of the Census, the then director of the government-supported publishing house of Balai Poestaka and a good colleague of

\footnotetext{
38 "Met de phrase 'volksonderwijs moet in de volkstaal gegeven worden' is men niet geholpen. Men heeft een conventioneele lees- en schrijftaal noodig, die men kan overneemen en naar de behoefte wijzigen waar zij reeds bestaat(-). Men bedenke dat overal het volksonderwijs, wel verre van de veelheid der volkstalen en dialecten te helpen bestendigen, krachtig heeft medewegewerkt om deze deels te doen ineensmelten, deels te doen verdwijnen. Het ligt in den aard en de bestemming van dit onderwijs, op het gebied der taal te streven naar centralisatie en verbreiding der kennis van één geestelijk gemeenschapsmiddel over een zo groot mogelijk gebied." See C. Snouck Hurgronje, Ambtelijke adviezen (derde deel), ed. E. Gobee and C. Adriaanse (The Hague: Nijhoff, 1965), p. 1807.

${ }^{39}$ Developments in the Dutch Indies show again how strongly conducive literacy and education are to the process in which heteroglossia is transformed into polyglossia: clear-cut standards and norms were created, with borders, exclusion, and selection, and with them an awareness of one's own identity.

40 "Geene taal heeft zoo onder stelselzucht geleden als de Maleische juist omdat er zoo weinig stelsel in is. Men houdt haar algemeen voor gemakellijk—dit blijkt genoeg uit de menigte van onbevoegde liefhebbers-en toch is het niemand harer talrijke beoefenaars nog gelukt haar duidelijk te maken." See C. Hooykaas, "Modern Maleisch, zijn verspreiding, bruikbaarheid en toekomst," Koloniale Studiën 1939, p. 411.
} 
Hooykaas could frankly write in an English publication: "Much will have to happen before Malay becomes anything more than a superficial means of elementary understanding. It does not seem that this by-language, no matter how well it is studied, will ever be able to replace the country tongue" 41 _ a remarkable statement in view of the activities this very publishing house was undertaking in its proudly and widely propagated efforts to create a new and modern Malay language and an equally new and modern Malay literature. A bizarre remark by the language engineer in optima forma, perfectly in tune with the discussions among Dutch experts that circled around the question as to how far Malay should be regarded a (tolerant) communication language ("verkeerstaal") or an (intolerant) language of culture ("cultuurtaal"). It seems as though scholars and administrators refused to accept the power and reach of their own creation!

The introduction of "Van Ophuysen Malay" was meant to be a solid step towards a standard Malay; it was meant to support centripetal forces in Dutch Indies society. The standard had been set, the compass had been constructed-but it did not really work beyond the school system. This particular kind of Malay was strongly associated with Dutch Authority, and while embitterment about the socio-political and economic situation merely increased, the natives often referred to it with the term Bahasa Belanda (Dutch) rather than bahasa Melayu; not all of them by any means felt compelled to use it. The same can be said of the foreign Orientals; the Chinese intellectual Kwee Tek Hoay even made the explicit vow that this "Riauw Malay" or "Van Ophuysen Malay" ("still protected by the Government") was soon to be replaced by another kind of Malay, "Low Malay." 42 Van Ophuysen did not have much effect either on the forms of Malay which Europeans themselves kept using until the fall of Dutch authority: "the gibberish that is used by 'totoks' who have neither knowledge of nor feeling for the language and that Brother Brown manages to understand thanks to his hereditary competence hardly deserves that name; rather, it is a kind of pidgin. It could only serve for the most elementary expressions of desire and certainly not for the transmission of thoughts, this bazaar-Malay." 43

\section{Segregation}

The efforts which Authority undertook in the first half of this century to impose order on the linguistic flexibility and to create clearly defined languages in the Indies had a double face. On the one hand, the position of Dutch was solidified; towards the end of the nineteenth century it turned away from tolerance and heterogeneity and surrounded itself with an aura of privilege and exclusiveness. On the other hand, Malay and the other vernaculars were defined and restricted, thus developing along lines Authority had not foreseen. In literature, the mirror of the Indies, a corresponding gap evolved: in Dutch novels that deal

\footnotetext{
41 See G.W.J. Drewes, "The Influence of Western Civilisation on the Languages of the East Indies Archipelago," in The Effect of Western Influence on Native Civilisation in the Malay Archipelago, ed. G. Schrieke (Batavia: Kolff, 1929), p. 153.

42 Quoted in Claudine Salmon, Literature in Malay by the Chinese of Indonesia-a Provisional Annotated Bibliography (Paris: Editions de la Maison des Sciences de l'homme, 1981), p. 116.

43 "het brabbeltaaltje waarvan i.h.b. niet taalkundig ontwikkelde en -gevoelige totoks zich bedienen, en dat de bruine broeder met hereditaire vaardigheid weet te begrijpen, verdient den naam taal nauwelijks, doch is een soort pidgin. Het kan slechts dienen tot de meest elementaire wilsuitingen, niet tot gedachten-overdracht, dit pasar-Maleisch." See Hooykaas, "Modern Maleisch," p. 408.
} 
with the Indies, the natives are treated with growing hostility and distrust, in Malay novels the Europeans are largely absent. ${ }^{44}$

This transformation of heteroglossia into polyglossia formed part of a more embracing movement in the Indies in the late colonial period: the European inhabitants there were forced to realize that the life-style they were entertaining with their Eurasian wives and native concubines was objectionable. Visitors and newcomers ("baren" they were called, those who came from the Motherland) made derogatory remarks about everyday life in the Indies as well as about the language that was used; authors and journalists had their pick of funny scenes, adding their own serious reflections about race and superiority. More painfully, these newcomers took leading positions in the administration, in economic and judicial life, in the army-and thus they progessively created a gap between a European lifestyle and an "Indian" life-style, the style of "liplaps" and bastards.

In 1870, the "baar" Busken Huet still showed some sympathy for those in the Indies who did not know "correct" Dutch; thirty years later Bas Veth, another much-discussed "baar," offered a radically negative picture of the linguistic hotchpotch in his bitter book about his sojourn in the Indies. At the time of publication, 1900, "Baren en Oudgasten" created considerable commotion in the Indies as well as in Holland. There was a great tradition of grousing about the situation in the Indies-think of Multatuli, Busken Huet, Walraven, and Du Perron-and Veth's book would have been amusing reading even today, were it not so explicitly racist.

The children [i.e. who are born in the Indies] do not feel the language they are speaking because they do not know the country and the climate where this language emerged. For their children, Dutch is a mere skeleton, this Dutch language. What do they know of the warm blood and the juicy muscles, of the ardor and supple force of our delightful words and idioms (-) it is painful for European parents when their children are raised in the Indies with no knowledge at all of the country where the language that they were speaking was born (-) This is another curse of the Indies. ${ }^{45}$

The unfamiliar forms of Dutch and the role they were playing in Indies' heteroglossiano pure language, no integrating and homogenizing form of Dutch-bewildered Veth, and he was certainly not the only one who expressed himself in negative terms. At the time of his stay in the Indies 70 percent of the children registered as "European" still did not know Dutch well enough to follow classes in a Dutch school without a problem. ${ }^{46}$

Dutchification: gradually a Dutch was imposed that was meant to be close to "algemeen beschaafd Nederlands," the form of the language spoken in the Motherland. The process

\footnotetext{
44 With the exception, of course, of the literature that was written by authors of Chinese descent-here Europeans often do play a role of importance.

45 "de kinderen voelen niet de taal, die ze spreken, omdat ze het land en het klimaat niet kennen, waar die taal ontstond. Voor hun kinderen is de taal een skelet, de hollandsche taal. Wat weten ze van het warme bloed en de malsche spieren, van den gloed en de soepele kracht onzer heerlijke woorden en zinswendingen. (-) Het is schrijnend-hard voor europeesche ouders als hun kinderen in Indië worden opgevoed en niet het land zullen kennen, waar de taal geboren is, die ze spraken (-) Ook dit is een vloek van Indie." (Bas Veth, Het leven in Nederlandsch-Indië (Amsterdam: Van Kampen \& Zoon, 1900), pp. 155-56.

46 See G. J. Nieuwenhuis, Bronnenboek voor het nieuwe taalonderwijs in Indie (Groningen: Wolters, 1925) p. 4 . The obvious source of all evil was childhood: children were often raised by native servants and their native values and concepts, and they spoke fluent Malay or Javanese before they spoke Dutch. In an article in Het Weekblad voor Indië in that same year 1906 (February 18, 1906) a subscriber complains that (European) mothers are constantly feeling obliged to punish their children because they are using Malay and Javanese-why show so much disgust for these beautiful languages?
} 
started in the 1860s when a system of formal education was set up that was not only meant for the sons (and later, daughters) of Europeans, but also for the sons of native rulers and "foreign orientals." 47 Growing familiarity with the Motherland's "language" was the direct result of this formal education. Better connections between Europe and the colony also played a role, as did the growing number of furloughs and holidays that were spent in Europe (and the dreams about them), as well as the growing number of immigrants who came in as the Indies was opened up to free enterprise after 1870.

The most decisive role in the Dutchification of the European population in the Indies, however, may have been played by Dutch women who, in growing numbers, followed their European husbands to the Indies and settled there. These white women made an end to concubinage, and by doing this, they "cut an essential link between the colonists and the native population." 48 They tried to have a Dutch family-life based on a Dutch pattern; they supported Dutch values and propagated the use of standard (civilized) Dutch. ${ }^{49}$ "The more 'pure' Dutch women marry by proxy and come to the Indies, the better," wrote Creusesol for instance: it would make an end to that awful " $\mathrm{G}(\mathrm{H})$ ollandsch of those Indian-blanda mamas who betoel-betoel feel insulted when they are thought to be natives because they are found guilty of maltreating our language." 50

White women took up a mission civilatrice; they feared to "verindischen" - "Some day we will return to Holland! let us not give in to the lethargy here! let us play the piano! no more rice! where is my knife and my fork! no more sirih!" And as a matter of course, complaints about the low quality (or even absence) of "cultural life" can be found in almost every narrative about life in the Indies. Those complaints tell us more about the differences between the Motherland and the colony than about Indies' cultural life itself; of course "culture" was not absent, but apparently it had developed along lines that made it invisible or even appalling to European newcomers. Those women who took their task to be bringing "high culture" to the Indies must have hated the country, so full of supposedly lazy, lethargic, and colored Europeans and natives, so green, so frightening. The widely respected woman author Marie van Zeggelen expressed the opinion of many a white woman in the Indies:

Women who are from an intellectual, artistic milieu lack everything here. It is horrible, that everlasting green, that everlasting sitting at home, to be surrounded by whitewashed walls, the boring visits to complete strangers, the insignificant small talk, the total absence of anything that is art. ${ }^{51}$

47 See Groeneboer's Weg tot het Westen.

48 T. Pollmann, "Bruidstraantjes, De koloniale roman, de njai en de apartheid," in Vrouwen in de Nederlandse koloniën, ed. G. Reijs et al. (Nijmegen: SUN, 1986), p. 112.

49 From a different perspective, Pierre Bourdieu dared to make a more general remark on this subject: "Women are more disposed to adopt the legitimate language (or the legitimate pronunciation): since they are inclined towards docility with regard to the dominant usages both by the sexual division of labor, which makes them specialize in the sphere of consumption, and by the logic of marriage, which is their main if not their only avenue of social advancement and through which they circulate upwards." See his essay, "The Production and Reproduction of Legitimate Language," in Language and Symbolic Power, ed. J. B. Thompson (Cambridge: Harvard University Press, 1991), p. 50.

50 " $\mathrm{G}(\mathrm{H})$ ollandsch der indische Blanda mama's die 't betoel-betoel kwalijk nemen als men haar voor Inlandschen houdt vanwege de mishandeling onzer taal, waaraan zij zich schuldig maken." in Creusesol, Naar de(n) Oost! (Utrecht: van der Heide \& Leijdenroth, 1908), p. 120.

51 "Vrouwen die uit een intellectuele, artistieke omgeving komen missen hier alles. Het is verschirkkelijk, dat eeuwige groen, dat eeuwige thuiszitten tussen de witgekalkte muren, de vervelende visites bij wildvreemden, 
Coming to this strange country often led women to loneliness and isolation, and to the Dutchification ${ }^{52}$ which is so finely summarized in Carry van Bruggen's Een Indisch huwelijk. In this short novel, one of the (male) figures says about the wife of one of his colleagues: "now she is playing the pioneer; she is spreading civilization. Once a month she invites the men for dinner in dinner jackets, she plays Schubert for them," and about another colleague: "the past few months, after he was married, Van Till became rather bookish. They read together, his wife and he. Incredibly civilizing. Really, she improved his pronounciation [of Dutch]."53

Isolation and Dutchification: the growing emphasis on Dutch identity inevitably resulted in an explicitly confessed hostility towards the natives, but also in a growing ignorance about them. These sentiments can be found scattered in almost any twentieth-century novel located in the Indies. Van Zeggelen once more:

My new companion could tell me quite a lot about the Indies; a real totok like I am could be in the tropics for years and still know nothing about those little mysteries. She may feel them, yet does not know them, because natives do not to wish to speak as freely with me as they do with Elly, for instance. Although she is as white as I am, people immediately know at a first glance: "This is someone from here, that is a foreigner." No matter how kind I am to a native, no matter how I may shower him with kindness, I will never acquire his full trust because deep inside there is the firm conviction that I am making fun of what is sacred to him. ${ }^{54}$

It was Boeka, a much neglected author, who probably formulated the gap in the simplest manner possible: "The native hates the Westerner." 55

Segregation instead of segmentation, race instead of caste, polyglossia instead of heteroglossia-the linguistic indifference that had been characteristic of the Indies for so long came to a slow end. After 1900, Europeans no longer accepted natives in their presence so easily, and the forms of Dutch-Malay and Malay-Dutch which until the beginning of the century had been widely used among European urbanites disappeared from the domestic life of Residents, lawyers, planters, and bankers, only to emerge in the poor people's areas. "The language which was heard in the highest circles a hundred years ago, in the middle circles fifty years ago, has now sunk to the lowest." 56 It was replaced by civilized "Motherland Dutch," for Europeans so that they could act like the true leaders of society, and for

die onbeduidende praatjes, de totale afwezigheid van alles wat kunst is." See M. van Zeggelen, Indrukken van een zwervelinge-de Hollandsche vrouw in Indië (Schoorl: Conserve, 1989), p. 83.

52 On this process, see Pollmann, "Bruidstraantjes."

53 "ze speelt nu pionierster. Ze verspreidt beschaving. Ze geeft ze (de mannen) nu eenmaal in de maand te eten in een zwarte jas, ze speelt Schubert voor ze" and: "Van Till was toch wel wat boekerig, deze laatste maanden sinds zijn trouwen. $\mathrm{Zij}$ lazen veel te zamen, zijn vrouw en hij.(..)Allemachtig beschavend. Ja-ze verbeterde zijn uitspraak." See C. van Bruggen, Een Indisch huwelijk (Amsterdam: Querido, 1921), pp. 23 and 16.

54 "Mijn nieuwe lotgenoote wist mij een massa dingen van Indië te vertellen, want een echte totok zoals ik ben kan jarenlang in de tropen zijn, zonder nog van al die kleine geheimzinnigheden afg te weten. Ze voelt ze wel, maar ze kent ze niet, want inlanders willen met mij nooit zo vrij uitspreken als ze dat b.v. met Elly doen. Hoewel zij even blank is als ik, weten de mensen uit het volk het bij de eerste kennismaking dadelijk: 'Dat is iemand uit het land, en dat is een vreemde.' Al ben ik nog zo vriendelijk tegen een inlander, al overlaad ik hem met goedheid, zijn volle vertrouwen krijg ik nooit, want diep in hem is de overtuiging dat ik hem uitlach om wat hem heilig is." See Van Zeggelen, Indrukken, p. 204.

55 "De inlander haat den Westerling." See Boeka, "De Inlander-een studie,"Indische Gids (1903), 2: 1169.

56 "Wat voor honderdjaar in de hoogste standen werd gehoord, voor vijftig in de middelste, is nu reeds afgedaald tot de laagste." See Nieuwenhuis, Bronnenboek, p. 5. 
some native sons (and daughters) so that Dutch officialdom would have some native colleagues on the same level of sophistication and knowledge through whom the increasingly complicated bureaucracy could be operated in a proper and cheap manner. ${ }^{57}$

In the 1920s the gap had stabilized, and the sphere was ripe for the full-blown positive defense of the Dutch language by G. J. Nieuwenhuis, who set himself up as the great propagator of Dutch in the Indies. In his numerous books and pamphlets, Nieuwenhuis worked from the assumption that Indies' Dutch had eventually to develop into a mere dialect, like Groningian and Brabantian. Dutch children were less and less exposed to "bad influences," and no longer was there any fear that Dutch would be really corrupted by the natives: the number of children who were learning Dutch, was relatively small and their training was now in the hands of European experts. ${ }^{58}$ After 1926, Nieuwenhuis himself was the selfacclaimed leader of these experts; he saw to it that government-subsidized schools substituted his textbooks for the wide variety of textbooks that in his view were based on outdated methods of teaching. In his book-long defense of Dutch and his own methods of teaching it (the so-called "Nieuw Taalonderwijs methode"), a series of remarks can be found that offer a good insight into the linguistic situation toward the end of colonial rule:

The language of officals has intruded deeper into the Indies language than the lively and colorful Dutch that only the common man's mouth is able to produce. The bookish Dutch so often heard here in the Indies is the result of this. And because its use is so often coupled with an insufficient mastery of the language, all sorts of errors occur which the totoks ridicule in so many jokes. The biggest error of the Croes method has been that it did not stop the tendency to misunderstand Dutch expressions from becoming worse, it even stimulated such misunderstandings. ${ }^{59}$

Such a remark was certainly not meant to please the 400,000 people in the Indies who, according to the 1930 Census, knew Dutch, "Civilized Dutch" (Algemeen beschaafd Nederlands) was not alive here, Nieuwenhuis claimed; the Dutch that was used by the locally trained Europeans and natives consisted of old-fashioned varieties, archaic, ridiculous. It was time to impose standard Dutch once and for all, even if only to a small part of the population.

Nieuwenhuis' main thesis is printed in bold type: "The task of the Dutch language in the Indies is: to help create a future for the Indonesians [sic], preserve a past for the Dutch." 60 Superior Western thinking had to be spread by way of a Western language, able to represent the international world, so long as there was no native language able to express

\footnotetext{
57 "Association policy" is the common name for this, as conceptualized by Snouck Hurgronje and his generation of scholar-administrators. But even upon this restricted policy of education Dutch officials did not agree, witness for instance Opheffer's scathing attack on Snouck Hurgronje who had suggested that native officials should be forbidden from speaking Dutch to their superiors. "Language" was becoming a very sensitive subject in the Indies. See Opheffer, Brieven, pp. 120-23.

58 Nieuwenhuis, Bronnenboek, p. 7.

59 "In het indisch (is) de ambtelijke schrijftaal meer doorgedrongen dan het levende kleurrijke Nederlandsch, dat alleen de volksmond brengen kan. Het boeken-Nederlandsch, dat zo vaak in Indië gehoord wordt, is er het gevolg van. En omdat het gebruik ervan vaak nog met onvoldoende taalbeheersching gepaard gaaat, komen de fouten in de wereld, waarover de totoks zich in tal van moppen zoo vroolijk maken. De grootste fout van de methode Croes was, dat het die neiging tot onbegrepen taal-uitingen, die zucht naar boekentaal niet alleen niet heeft tegengegaan, maar dat die nog sterk heeft bevorderd." See Nieuwenhuis, Bronnenboek, p. 55.

60 "De taak van het Nederlandsch in Indië is: voor de Indonesiërs een toekomst te helpen scheppen, voor de Nederlanders een verleden te bewaren." G. J. Nieuwenhuis, Het Nederlandsch in Indië-een bronnenboek (Groningen-Batavia: Wolters,1930), p.9.
} 
concepts and ideas in a careful and precise manner. It would take a long, long time before any of the native languages could reach the same level of precision and strength. Only in a faraway future would a number of these "pure" languages coexist peacefully in the Indies, on the basis of full equality. In complete contradiction to this mild attitude towards native languages was Nieuwenhuis' repeated claim that Dutch should become the authoritative language of communication in the Indies, certainly not Malay:

Everything we are doing to make Malay the lingua franca works against our efforts to spread our language, to introduce international culture, to implement a unification on a higher level, and also against the perpetuation of our interests. In other words, it could only be disadvantageous for the Indies as well as for the Netherlands. ${ }^{61}$

An emotional outburst maybe, but a dangerous one at that as it was made from a safe position of Authority. On the one hand the use of Malay was propagated, on the other it was disclaimed-what were native intellectuals supposed to do?

It was not only so-called experts like Nieuwenhuis ${ }^{62}$ who felt uneasy about the Croes method; native intellectuals who had the privilege of a Dutch education did as well. The teacher Soewarsih Djojopoespito, for instance, gives a bitter picture of it in her Dutch novel Buiten het Gareel, in which the husband of the heroine complains:

It greatly annoys me that our colleagues do not show the slightest interest in modern education, that is to say: they act like machines, they are rusted away in their old methods (-) At times I respect them, but oh that boring, that lethargic attitude towards everything new! They were taught the Croes method, and so they stick to that method. ${ }^{63}$

Why were natives like Soewarsih's heroes and heroines (and Soewarsih herself) interested in learning Dutch at all in this racial society? Why were they even obsessed by it? The answer is obvious: Dutch was the language which had the aura of prestige; mastery of Dutch was synonymous with Authority, with hegemony, with central power, with the top of the hierarchy. Knowing this language was a precondition for continuing one's Western education and, subsequently, for enlarging one's chances of getting a better paid job, climbing higher in the hierarchy, coming closer to the upper class, the superior race. Often enough, natives spared neither trouble nor expense to have members of their family get some education in the Dutch language. They were even willing to accept the humiliations that the whites inflicted upon them.

My Dutch ... ah ... it bothers me, no, that is to say: the oral part of the exam (for the teaching certificate) does. As for the written part, I am safe, well, it is not really hard to write an essay about a runaway maid and dish it up with some hot sauce. But why are their requirements so high?! God knows how much trouble I took to get that thick $b$ and

61 "alles wat we doen om het Maleisch tot lingua franca te maken, werkt de verbreiding van onze taal, de doordringing van de internationale cultuur, de unificatie op hooger niveau en ook de bestendiging van onze belangen tegen, is dus Indië zoowel als Nederland tot nadeel." See Nieuwenhuis, Het Nederlandsch, p. 49.

62 About Nieuwenhuis and his ideas, see, e.g., K. Groeneboer, "Nieuw Taalonderwijs," in Studi Belanda di Indonesia, ed. K. Groeneboer (Jakarta: Jambatan, 1989), pp. 319-22.

63 "Het ergert me dat de collega's helemaal geen belangstelling voor het moderne onderwijs hebben, dat wil zeggen: dat ze alles zo mechanisch doen, vastgeroest als ze zijn in hun oude methoden. (-) Soms vind ik hen flink, maar die saaie, die slome houding tegenover al wat nieuw is! Ze hebben de methode van Croes op school gehad, dus volharden ze in die methode." See Soewarsih Djojopoespito, Buiten het Gareel (Amsterdam: Nijgh \& Van Ditmar, 1986), p. 74. 
$d$ out of my accent. You use a little mirror for this; when I am just talking, everything is fine but as soon as I get enthusiastic, no. .. !64

A fine suggestion of the relentless drill Dutch teachers imposed upon the happy few who were given the privilege of learning this strange and powerful language. Like Soewarsih, like Sjahrir. But then the frustration came from the "psychopathic inhabitants," "the sadists," and the ones "who suffer from megalomania," Sjahrir wrote about. Authority tended to impose pathological restrictions upon those who, armored with knowledge of the mysterious language and the knowledge that it hid, tried to climb the social ladder. Humiliations were only accepted up to a certain point, and sooner or later the excitement among native intellectuals took the form of embitterment. Another of the many barriers the Dutch created.

Seen from the other side, from the point of view of Authority: why propagate the use of Dutch? Education was expensive, and a leading theme in Dutch colonial policy was the worry about spending too much money; if only for that reason, the Dutch language should not be taught to too many people. Moreover, the natives were inferior anyway, so there was no point in spreading Dutch and all the knowledge that came with it. Thirdly, it could harm Dutch interest's if too many natives knew Dutch: they would be given the key to sacred and secret knowledge, and although consequences were hard to predict, the majority of the European population was convinced that it could only lead to a political, social, cultural instability and chaos in which the Dutch could no longer perform their civilizing and ordering task.

This all could be regarded as a hardening of the sentiments that can already be found as early as 1892 in Adinda's Vrouwen lief en leed onder de tropen in which the narrator had this to say about a servant who spoke excellent Dutch, for a Javanese that is to say:

had his masters been in the Indies longer, they would have realized that this was certainly not an advantage because natives lose respect for their masters as soon as they know the language, and without such respect Indies society can not possibly exist. ${ }^{65}$

The 1930 Census showed the gap in all its glory. The natives had to be held at bay. A safe guarantee had to be created for an efficient government which could only be run by superior and well-educated Europeans. Ward off chaos and disorder. Maintain law and stability. Shape mutual respect.

\section{Dutch and Malay}

The advantages which a selective spread of the Dutch language could have for the Netherlands is presented in bold print in Nieuwenhuis' book:

If out of the indigenous population, eventually one million cultured people speak or understand our language (just $2 \%$ of the population), then Dutch books, Dutch workers,

64 "Mijn Nederlands ... oho ... zit me dwars, nee, dat is te zeggen, het mondelinge gedeelte. Voor het schriftelijk ben ik veilig, nu ja, een opstel over een weggelopen baboe met een pikant sausje opgediend is niet zo moeilijk. Maar ze eisen zoveel. God weet wat een moeite ik heb gedaan om die dikke $b$ en $d$ uit mijn accent weg te werken. Je werkt met een spiegeltje daarvoor; als ik gewoon praat, gaat het wel, maar als ik enthousiast word, ho maar.." See Soewarsih, Buiten het Gareel, p. 81.

65 "waren ze langer in Indië geweest, dan zouden ze hebben ingezien, dat dit geen voordeel was, want zodra de inlanders de taal hunner gebieders spreken verliezen zij het respect voor hen, zonder het welk de Indische maatschappij onmogelijk kan bestaan." See Adinda, Vrouwen lief en leed onder de tropen, pp. 211-12. 
Dutch thoughts will keep their influence and Dutch products will keep their market during the long period in which the colony will become an independent state. 66

This should be read as the inevitable conclusion of a hundred years of language policy: colonial thinking in its purest form-and as is the case with so many ideas that were born in the colonial situation: it is too bizarre to give it a fair judgement even in retrospect. Conservative groups like the Vaderlandsche Club, conservative journalists like Zentgraaf must have loved phrases like this-a scholarly vindication for racial segregation, for polyglossia was welcome.

Of course there were scholars and administrators who were able to explain this gap in more positive terms. The natives are different from us, we are the "others," and in this line of argumentation it is easy to see that the natives should remain as native as possible. Their institutions demanded careful study, their ideology and values should be strengthened, they should only very selectively be touched by the achievements of Western culture. This kind of respect was inspired by the so-called "ethical school" of scholars like Van Vollenhoven, Van Deventer, and Snouck Hurgronje who found support in the literary work of authors like Van Zeggelen and de Wit; the eloquent group of intellectuals around "De Stuw" and "De Fakkel" in the late 1930s operated in their spirit. "Indology" - the "ethical school" it was called - taught Leiden students to protect the natives against too much involvement with outsiders so that the natives could preserve and strengthen their cultural identity. The use of Malay and other native languages was actively stimulated, efforts were made to discover the adat laws that allegedly reflected native values and concepts. Of course adat was not discovered but invented-just like Malay, just like Javanese and all the other native languages that had never been codified and standardized before in such a radical and far-reaching fashion. Some colonials meant well, others did not. Some wanted to ward off the native threat, others to protect native identity. The effect was the same: a growing segregation, socially, culturally, linguistically.

It should make us aware at least of the fact that scholars who are trying to justify a colonial situation are a painful sight, maybe even more so than politicians. The desirability of Dutchification, the degree of Dutchification, the quality of Dutchification-they led to heated debates in which scholars were the well-respected partners of administrators, bureaucrats, politicians. The same could be said of the discussions around the main complements of this Dutchification: Malayization and nationalism. Debates were lively and inspiring for those involved, no doubt. They may have been too non-committal, however, too informal in a way, too much conducted from the safe throne of Authority, based on too little information of what was going on among "the others." Nationalism, for instance. Hate. Psychopathology. Inferiority-complexes.

Most of the Dutch Indies policy makers were living in a dream, it seems. Their ideas about the function and role of Dutch were shrewd, naive, or just stupid-and often they were a curious combination of the three. Their ideas about the role of Malay (and of the other local "languages" for that matter) remained vague, unspecified, and inconsistentand so were their ideas about nationalism and discontent. That should not surprise us: this was about the "others," and the "others" had to be contained, controlled, excluded from privileges rather than understood and appreciated in their own right. That attitude explains

66 "Als op den duur een millioen ontwikkelde Indiërs onze taal spreekt of verstaat (nog maar $2 \%$ van de bevolking) blijven Hollandsche boeken, Hollandsche werkers, Hollandsche gedachten hun invloed behouden en Hollandsche waren aftrek vinden gedurende de lange periode door die van kolonie naar zelfstandige staat voert." See Nieuwenhuis, Het Nederlandsch, p. 14. 
some of the bizarre omissions in the Census Report of 1930. It explains the tensions and conflicts the report tried to hide; it could be read in various ways: even cool and scientific figures are open to many interpretations. 
